\title{
Multi-dose applying EDTA to decrease the potential groundwater contamination using rainbow pink (Dianthus chinensis) for enhanced phytoextraction
}

\author{
Hung-Yu Lai, Zueng-Sang Chen* \\ Graduate Institute of Agricultural Chemistry, National Taiwan University, No. 1, Sec. 4, \\ Roosevelt Rd., Taipei 10617, Taiwan \\ Tel.+886 (2) 2369-8349; Fax+886 (2)2392-4335; email: soilchen@ntu.edu.tw
}

Received 24 October 2005; revised 11 March 2006; accepted 11 May 2006

\begin{abstract}
Synthetic chelating agents are used to increase the phytoextraction of metals from contaminated soils, however the increased bioavailability of the metals may increases the potential risk of groundwater contamination. In this study, 4 mmol EDTA $\mathrm{kg}^{-1}$ was applied using four application methods to a $\mathrm{Cd}-, \mathrm{Zn}$-, and $\mathrm{Pb}$-contaminated soil to evaluate the effects of multi-dose EDTA application on the metals concentrations in the soil solution, soil (as extracted by different methods), and shoots of rainbow pink (Dianthus chinensis). Results showed that application of $4 \mathrm{mmol} \mathrm{kg}^{-1}$ one time or application of $2 \mathrm{mmol} \mathrm{kg}^{-1}$ two times, significantly decreased the concentration of Cd, $\mathrm{Zn}$, and $\mathrm{Pb}$ in the soil solution at the end of experiment (42nd day) compared with the application of $0.67 \mathrm{mmol} \mathrm{kg}^{-1}$ six times during 6 weeks experiments. Application of $2 \mathrm{mmol} \mathrm{kg}^{-1}$ two times significantly decreased the deionized water-extractable $\mathrm{Cd}$ and $\mathrm{Pb}$ concentrations in the soil compared with the application of $0.67 \mathrm{mmol} \mathrm{kg}^{-1}$ six times. However, there were no any effects of the different application methods on the concentration and total removal of $\mathrm{Cd}, \mathrm{Zn}$, and $\mathrm{Pb}$ in the shoots of rainbow pink. Results revealed that application of $2 \mathrm{mmol} \mathrm{kg}^{-1}$ two times was effective to decrease the potential groundwater contamination.
\end{abstract}

Keywords: Phytoextraction; EDTA; Rainbow pink; Cd; Zn; Pb

*Corresponding author.

Presented at the 9th Environmental Science and Technology Symposium, September 1-3, 2005, Rhodes, Greece. Organized by the Global NEST organization and prepared with the editorial help of the University of Aegean, Mytilene, Greece and the University of Salerno, Fisciano (SA), Italy. 


\section{Introduction}

Metal-contaminated soils can be restored by the technique of phytoextraction, which uses the roots of plants to take up metals in soils and then transfer them into the shoots [1-5]. The harvested plant tissues are then subjected to composting, compaction, incineration, ashing, pyrolysis, direct disposal, or liquid extraction [6]. Over 420 species of hyperaccumulator plants from all over the world can accumulate high concentrations of metals in contaminated sites [7], but many of them have low growth rate and biomass and consequently low capacity to remove metals from the soil. Thus, they need much time to remove metals from contaminated soils. Phytoextraction can be enhanced by several methods such as by applying synthesized chelating agents [8-13], chemical amendments $[5,14]$, genetic engineering [15-17], and agronomic practices $[18,19]$.

Various synthesized chelating agents can be added to the metal-contaminated soils to increase metal mobility and bioavailability and thus, increase the concentrations of metals in the shoots of plants. These include EDTA (ethylenediaminetetraacetic acid), DTPA (diethylenetrinitrilopentaacetic acid), HEDTA (hydroxyethylenediaminetriacetic acid), CDTA (trans-1, 2-cyclohexylenedinitrilotetraacetic acid), and EGTA (ethylenebis (oxyethylenetrinitrilo)tetraacetic acid) $[8,9,11,12$, 20,21]. In single metal-contaminated soils, especially with $\mathrm{Pb}$, applying synthetic chelating agents can increase both the solubility of metal in the soil solution and the concentration of metal in the shoots of plants $[8,9,12]$. However, the application of synthetic chelating agents can reduce both the biomass of the plant and the total removal of metals in combined metals-contaminated soils because of the interaction of other metals [11]. The EDTA-metal complex is resistant to degradation by soil microorganisms; it was observed in the soil solution 5 months after EDTA application $[11,22]$. Application of EDTA to increase phytoextraction thus poses some risks of ground- water contamination, especially for soils with higher groundwater table or for sandy soils. Shen et al. [23] reported that multi-dose EDTA application was efficient in increasing the $\mathrm{Pb}$ concentration in the shoot of the cabbage and was able to decrease the potential of groundwater contamination. Multi-dose EDTA application technique was thus used in this study to decrease the risk of groundwater contamination.

The use of garden plants to remove metals from contaminated soils is a popular and satisfactory strategy because it enables the contaminated sites to recover to their natural condition. It also generates economic returns if appropriate flower species are cultivated. Chen and Lee [24] showed that when rainbow pink (Dianthus chinensis) was grown in a Cd-contaminated site in northern Taiwan for five weeks, the Cd concentration in the shoot of the plant increased from 1.6 (initial) to $115 \mathrm{mg} \mathrm{kg}^{-1}$ (73.7-fold), and the total Cd uptake was about $100 \mathrm{~g} \mathrm{ha}^{-1} \mathrm{y}^{-1}$. Cd concentration in the leaves of rainbow pink can reach the threshold (100 mg Cd kg ${ }^{-1}$ ) of a Cd hyperaccumulator [7]. Lai and Chen $[25,26]$ reported that applying 5 or 10 mmol EDTA kg ${ }^{-1}$ to a Cd-, Zn-, and Pb-contaminated soil significantly increased the concentrations of these metals in the soil solution and in the shoots of rainbow pink $(p<0.05)$. Total $\mathrm{Pb}$ removal by the shoot of rainbow pink also increased significantly $(p<0.05)$. These results show that this plant species is a potential hyperaccumulator which can be used for the phytoextraction of metals in combined metal-contaminated soils.

In this study, 4 mmol EDTA kg-1 was applied using different methods to assess the effect of multi-dose EDTA application on the phytoextraction of metal by rainbow pink. The objectives of this study were (i) to evaluate the effects of multidose EDTA application on decreasing the $\mathrm{Cd}, \mathrm{Zn}$, and $\mathrm{Pb}$ concentration in soil solution and soil when rainbow pink was grown in a $\mathrm{Cd}-, \mathrm{Zn}$-, and $\mathrm{Pb}$ contaminated soil, and (ii) to evaluate the effects of multi-dose EDTA application on the uptake of these metals by rainbow pink. 


\section{Materials and methods}

\subsection{Soil characteristics}

A rural soil contaminated by the discharged wastewater of chemical plants was used in the pot experiments. The $\mathrm{pH}$ value of the soil was determined using glass electrodes in a soil to water ratio of 1:1 [27]. Soil particle-size distribution was analyzed using the pipette method [28], organic carbon content (OC) by the Walkley-Black wet combustion method [29], cation exchange capacity (CEC) by the ammonium acetate at $\mathrm{pH} 7$ method [30,31], and the total concentration of $\mathrm{Cd}$, $\mathrm{Zn}$, and $\mathrm{Pb}$ in the contaminated soil by digestion with aqua regia and quantification by atomic absorption spectrometer (AAS, Hitachi 180-30 type) [32].

\subsection{Artificial addition of $\mathrm{Cd}, \mathrm{Zn}$, and $\mathrm{Pb}$}

The same as our previous study [26], the combined metals-contaminated soil used in this study was artificially added with $\mathrm{Cd}\left(\mathrm{NO}_{3}\right)_{2} \bullet 4 \mathrm{H}_{2} \mathrm{O}, \mathrm{ZnO}$, and $\mathrm{Pb}\left(\mathrm{NO}_{3}\right)_{2}$ to control the total concentration of the three metals (individual element concentration) of $20 \mathrm{mg} \mathrm{Cd} \mathrm{kg}{ }^{-1}, 500 \mathrm{mg} \mathrm{Zn} \mathrm{kg}{ }^{-1}$, and $1,000 \mathrm{mg} \mathrm{Pb} \mathrm{kg}{ }^{-1}$, respectively. The treated soil were wetted for two weeks by adding deionized water to maintain the water content at $60 \%$ of its total water-holding capacity (WHC) to enable the added metals to reach a steady state. Then, the soil was air-dried at room temperature for approximately four weeks. The artificially contaminated soil was subjected to three cycles of wet and dry processes before pot experimentation [8]. Its total concentrations of $\mathrm{Cd}, \mathrm{Zn}$, and $\mathrm{Pb}$ were determined after aqua regia digestion by AAS (Hitachi 180-30 type) [32].

\subsection{Pot experiments and laboratory analysis}

Each pot (16 cm diameter and $19 \mathrm{~cm}$ height) contained $3.0 \mathrm{~kg}$ (dry weight) of the combined metal-contaminated soils. Two rhizon soil moisture samplers (RSMS; Eijkelkamp Company, The
Netherlands) were put in each pot at a depth of around $10 \mathrm{~cm}$ below the soil surface. One seedling of rainbow pink (D. chinensis) was planted in each pot. The pot experiments were conducted in the phytotron using a randomized complete block design with a number of treatments and four replicates. The soil moisture content was maintained at $60 \%$ of the WHC by weighing and adding deionized water every $2 \mathrm{~d}$.

The same amount of 4 mmol $2 \mathrm{Na}$-EDTA kg-1 was multi-dose applied to the combined metalscontaminated soils $7 \mathrm{~d}$ after planting using the following application methods: (1) applying 4.0 mmol EDTA $\mathrm{kg}^{-1}$ at one time (4 mmol $\left.\times 1\right)$, (2) applying $2.0 \mathrm{mmol} \mathrm{EDTA} \mathrm{kg}^{-1}$ two times $(2 \mathrm{mmol}$ $\times 2$ ), (3) applying $1.0 \mathrm{mmol} \mathrm{EDTA} \mathrm{kg}^{-1}$ four times ( $1 \mathrm{mmol} \times 4$ ), and (4) applying $0.67 \mathrm{mmol}$ EDTA $\mathrm{kg}^{-1}$ six times $(0.67 \mathrm{mmol} \times 6)$. The adding time of the different concentrations of EDTA solutions is shown in Table 1. The growth characteristics and observable toxicity symptoms displayed by the plants were also recorded. The shoots of rainbow pink in all treatments were harvested $49 \mathrm{~d}$ after planting. The harvested plants were rinsed first with tap water to remove the attached soil particles, and then with deionized water. The harvested plants were oven-dried at $60^{\circ} \mathrm{C}$ for $72 \mathrm{~h}$, weighed, and ground to $0.5 \mathrm{~mm}$ by a grinder for chemical analysis. Exactly $0.2 \mathrm{~g}$ of the ground plant tissue samples were digested with $\mathrm{H}_{2} \mathrm{SO}_{4} /$ $\mathrm{H}_{2} \mathrm{O}_{2}$ [33]. The digested solutions were filtered through Whatman No. 42 filter papers $(2.5 \mu \mathrm{m}$ pore size), and then diluted with deionized water to a volume of $50 \mathrm{~mL}$ in a flask. The $\mathrm{Cd}, \mathrm{Zn}$, and $\mathrm{Pb}$ concentrations in the digested solutions were determined by inductively coupled plasma optical emission spectrometer (ICP-OES, Perkin Elmer 2000 DV).

Soil solutions were collected directly by a RSMS before adding the EDTA solutions, and 7, $14,21,28,35$, and $42 \mathrm{~d}$ after first adding the EDTA solutions. After harvest, the concentrations of $\mathrm{Cd}$, $\mathrm{Zn}$, and $\mathrm{Pb}$ in the tested soil were extracted by deionized water [34], $0.05 \mathrm{M}$ EDTA (pH 7.0) [34], 
Table 1

The adding time of different EDTA applying methods

\begin{tabular}{|c|c|c|c|c|c|c|c|c|}
\hline \multirow[b]{2}{*}{$\begin{array}{l}\text { EDTA concentration } \\
\left(\mathrm{mmol} \mathrm{kg}^{-1} \text { soil }\right)\end{array}$} & \multicolumn{8}{|c|}{ Duration of planting (d) } \\
\hline & 0 & 7 & 14 & 21 & 28 & 35 & 42 & 49 \\
\hline 4.0 & & + & & & & & & $\mathrm{H}$ \\
\hline 2.0 & & + & + & & & & & $\mathrm{H}$ \\
\hline 1.0 & & + & + & + & + & & & $\mathrm{H}$ \\
\hline 0.67 & & + & + & + & + & + & + & $\mathrm{H}$ \\
\hline
\end{tabular}

: Applying EDTA

H: Harvest

Table 2

The physical and chemical characteristics of the study soil

\begin{tabular}{lllllll}
\hline $\mathrm{pH}\left(\mathrm{H}_{2} \mathrm{O}\right)$ & $\mathrm{OC}\left(\mathrm{g} \mathrm{kg}^{-1}\right)$ & Texture & & $\mathrm{CEC}\left(\mathrm{cmol}_{(+)} \mathrm{kg}^{-1}\right.$ soil $)$ & \multicolumn{4}{l}{ Total concentration $\left(\mathrm{mg} \mathrm{kg}^{-1}\right)$} \\
\cline { 4 - 6 } & & & $\mathrm{Cd}$ & $\mathrm{Zn}$ & $\mathrm{Pb}$ \\
\hline 4.9 & 16.9 & Silty clay & 13.9 & $2.6 \pm 0.08$ & $80.0 \pm 5.3$ & $31.3 \pm 2.1$ \\
\hline
\end{tabular}

and 0.005 M DTPA (pH 5.3) [35]. Analysis of the metals in both the soil solution and the different soil extracts was done by ICP-OES (Perkin Elmer 2000 DV).

\subsection{Statistics}

The variance and significance of the differences among the concentrations of $\mathrm{Cd}, \mathrm{Zn}$, and $\mathrm{Pb}$ in the soil solutions, extracts, and in the plants were analyzed by ANOVA. Statistical significance was defined as $p=0.05$.

\section{Results and discussion}

\subsection{Soil characteristics}

Table 2 shows the physical and chemical characteristics of the studied soil. Soil texture was silty clay, with moderate cation exchange capacity of $13.9 \mathrm{cmol}_{(+)} \mathrm{kg}^{-1}$, a pH of 4.9 , and an organic carbon content of $16.9 \mathrm{~g} \mathrm{~kg}^{-1}$. The original total concentrations of the metals in the contaminated soil, digested by aqua regia, were $2.58 \pm 0.08 \mathrm{mg} \mathrm{Cd}$ $\mathrm{kg}^{-1}, 80.0 \pm 5.3 \mathrm{mg} \mathrm{Zn} \mathrm{kg}$, and $31.3 \pm 2.1 \mathrm{mg} \mathrm{Pb}$ $\mathrm{kg}^{-1}$. After artificially adding the metal solutions, the final concentrations of $\mathrm{Cd}, \mathrm{Zn}$, and $\mathrm{Pb}$ in the combined metal-contaminated soil were $19.0 \pm 1.7$, $503 \pm 44$, and $931 \pm 55 \mathrm{mg} \mathrm{kg}^{-1}$, respectively. These were close to the expected target concentrations of $20 \mathrm{mg} \mathrm{Cd} \mathrm{kg}^{-1}, 500 \mathrm{mg} \mathrm{Zn} \mathrm{kg}{ }^{-1}$, and 1,000 mg $\mathrm{Pb} \mathrm{kg}{ }^{-1}$.

\subsection{Effects on metal concentrations in soil solu- tions}

Fig. 1 shows the $\mathrm{Cd}, \mathrm{Zn}$, and $\mathrm{Pb}$ concentrations in the soil solution collected $42 \mathrm{~d}$ after applying the total amount of 4 mmol EDTA $\mathrm{kg}^{-1}$ through the different application methods. At the end of experiment (42nd d), both the application methods of $4 \mathrm{mmol} \times 1$ or $2 \mathrm{mmol} \times 2$ significantly decreased the $\mathrm{Cd}, \mathrm{Zn}$, and $\mathrm{Pb}$ concentrations in the soil solution compared with that of $0.67 \mathrm{mmol}$ $\times 6(p<0.05)$. The $\mathrm{Cd}$ and $\mathrm{Zn}$ concentrations in the soil solution significantly decreased from 


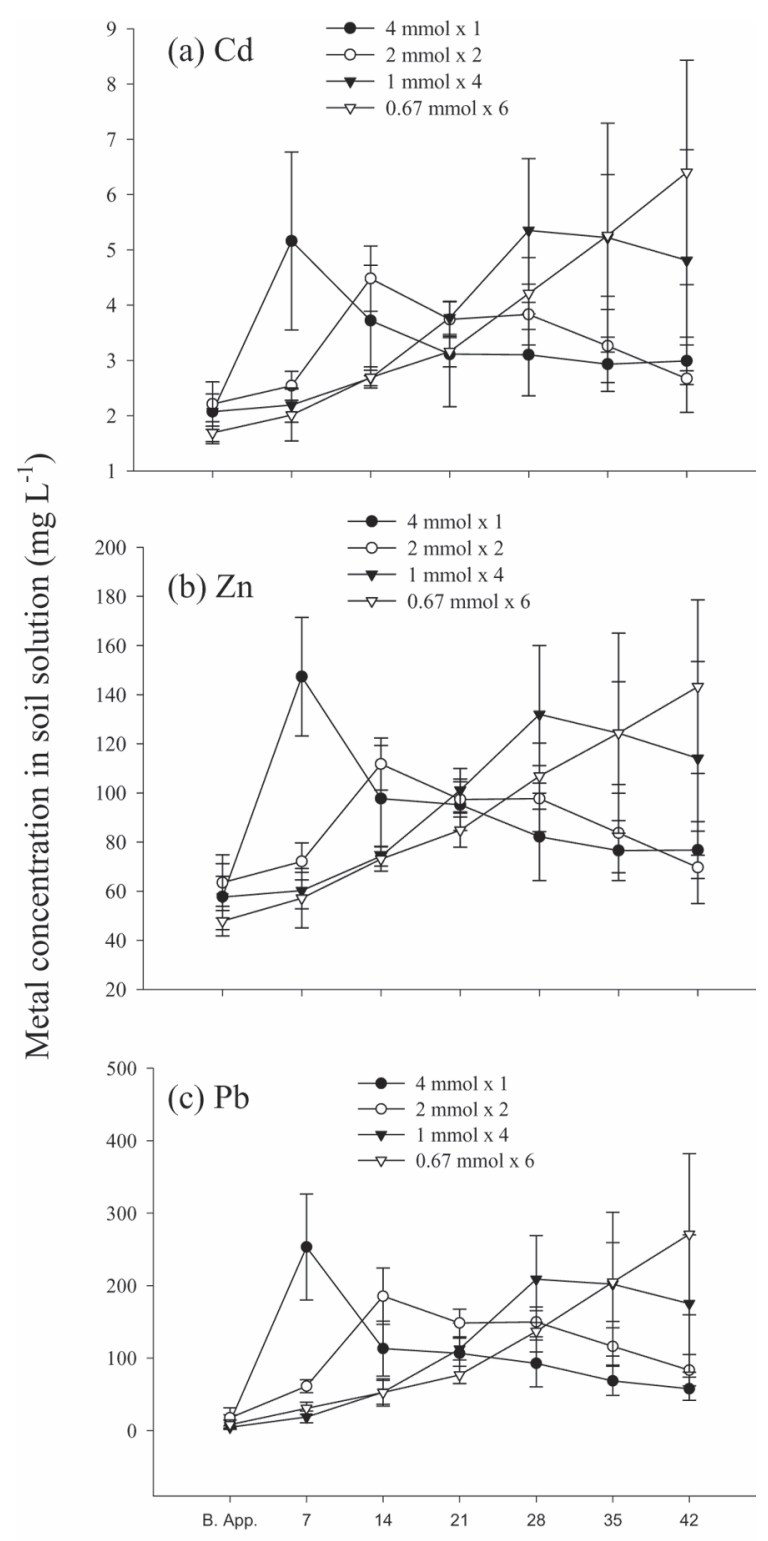

Duration after applying EDTA (d)

Fig. 1. The concentrations change of (a) Cd, (b) Zn, and (c) $\mathrm{Pb}$ in soil solution after applying EDTA with different methods. The soil solutions were sampled before applying (B. App.) and at 7th, 14th, 21st, 28th, 35th, and $42 \mathrm{nd}$ d after applying EDTA, respectively. Replicates $(n)$ $=4$.
$6.40 \pm 2.0$ and $143 \pm 35.3 \mathrm{mg} \mathrm{L}^{-1}$ (in the treatment of $0.67 \mathrm{mmol} \times 6)$ to $2.67 \pm 0.61$ and $69.7 \pm$ $14.7 \mathrm{mg} \mathrm{L}^{-1}$ (in the treatment of $2 \mathrm{mmol} \times 2$ ), respectively $(p<0.05)$. $\mathrm{Pb}$ concentration in the soil solution also significantly decreased from $271 \pm$ $111 \mathrm{mg} \mathrm{L}^{-1}$ (in the treatment of $0.67 \mathrm{mmol} \times 6$ ) to $83.4 \pm 21.5 \mathrm{mg} \mathrm{L}^{-1}$ (in the treatment of $4 \mathrm{mmol} \times 1$ ) $(p<0.05)$. After applying $4 \mathrm{mmol} \mathrm{EDTA} \mathrm{kg}^{-1}$ at $2 \mathrm{mmol} \times 2$, the $\mathrm{Cd}, \mathrm{Zn}$, and $\mathrm{Pb}$ concentrations in the soil solution were $42 \%, 49 \%$, and $31 \%$, respectively, of the concentrations obtained with the $0.67 \mathrm{mmol} \times 6$. The application of $4 \mathrm{mmol}$ EDTA $\mathrm{kg}^{-1}$ to the combined metals-contaminated soils either as $4 \mathrm{mmol} \times 1$ or $2 \mathrm{mmol} \times 2$ significantly decreased the concentrations of $\mathrm{Cd}, \mathrm{Zn}$, and $\mathrm{Pb}$ in the soil solution at the end of experiment (42nd d) compared with the method of $0.67 \mathrm{mmol} \times 6$ $(p<0.05)$. There was only a $7-d$ gap between the last dose of application of $0.67 \mathrm{mmol} \mathrm{EDTA} \mathrm{kg}^{-1}$ and the sampling of soil solution and this was shorter compared with the other application methods. The increased $\mathrm{Cd}, \mathrm{Zn}$, and $\mathrm{Pb}$ concentrations in the soil solution indicates that EDTA was not degraded during the 7-d period because of the resistant characteristic of the EDTA-metal complex in the soil solution $[11,22]$. The application of $0.67 \mathrm{mmol}$ EDTA $\mathrm{kg}^{-1}$ six times $(0.67 \mathrm{mmol} \times 6)$ was thus not able to decrease the metal concentration in the soil solution because of too many applications during the $49-\mathrm{d}$ period.

Soil solution samples were collected before applying and at 7th, 14th, 21st, 28th, 35th, and 42nd d after applying EDTA solutions to evaluate the changes of metals' concentrations after applying a total amount of 4 mmol EDTA kg-1 using different application methods. At 7th d after the different concentrations of EDTA solutions were first applied, the $\mathrm{Cd}, \mathrm{Zn}$, or $\mathrm{Pb}$ concentration in the soil solution was higher in the $4 \mathrm{mmol}$ $\times 1$ treatment than in the other treatments (Fig. 1). Results revealed that applying higher concentra-

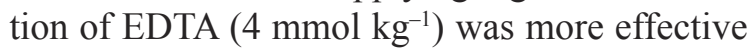
in increasing the concentration of metals in the soil solution compared with other concentrations 
of EDTA solutions. The experimental result was similar to that of Lai and Chen [25]. At 7th d after applying 4 mmol EDTA $\mathrm{kg}^{-1}$, the Cd concentration in the soil solution significantly increased from $2.10 \pm 0.54$ to $5.20 \pm 1.60 \mathrm{mg} \mathrm{L}^{-1}$ (2.5-fold) $(p<0.05)$, the $\mathrm{Zn}$ and $\mathrm{Pb}$ concentration also significantly increased from $57.8 \pm 13.4 \mathrm{mg} \mathrm{L}^{-1}$ and $11.8 \pm 10.0 \mathrm{mg} \mathrm{L}^{-1}$ to $147 \pm 24 \mathrm{mg} \mathrm{L}^{-1}$ (2.5-fold) and $253 \pm 73 \mathrm{mg} \mathrm{L}^{-1}$ (21.4-fold), respectively $(p<0.01)$. Because of the larger formation constant of the EDTA-Pb complex $\left(\log K_{f}=19.0\right)$ compared with both complexes of EDTA-Cd $\left(\log K_{f}=17.4\right)$ and EDTA-Zn $\left(\log K_{f}=17.5\right)$, the application of EDTA has greatest effect in increasing the $\mathrm{Pb}$ concentration in the soil solution among the three metals. The result was similar to that of previous studies [8,9,11,12,25,26].

Even though soil-soluble metals might be absorbed by soil particles or colloid materials while it was leached downward to deeper soil layer, higher concentration of EDTA-metal complex in the soil solution after EDTA application will produce a high potential contamination of groundwater. Lower metal concentration in soil solution during the experimental period therefore has lower risk of groundwater contamination compared with the higher one. During the period of the pot experiment, the maximum concentration of $\mathrm{Cd}$ in the soil solution after the different application methods of $4 \mathrm{mmol} \times 1,2 \mathrm{mmol} \times 2,1 \mathrm{mmol} \times 4$, and $0.67 \mathrm{mmol} \times 6$ were $5.2 \pm 1.6,4.5 \pm 0.59,5.4 \pm 1.3$, and $6.4 \pm 2.0 \mathrm{mg} \mathrm{L}^{-1}$, respectively (Fig. 1a). The application method of $2 \mathrm{mmol} \times 2$ had lower concentration of $\mathrm{Cd}$ in the soil solution compared with the other three application methods. Although the maximum concentration in the soil solution was beyond the threshold value for the groundwater of Taiwan $\left(0.05 \mathrm{mg} \mathrm{Cd} \mathrm{L}^{-1}\right)$, however, two-time application of $2 \mathrm{mmol} \mathrm{EDTA} \mathrm{kg}^{-1}$ could decrease the $\mathrm{Cd}$ concentration in the soil solution compared with the other application methods. The concentration change of $\mathrm{Zn}$ and $\mathrm{Pb}$ in the soil solution was similar with that of $\mathrm{Cd}$ during the period of the pot experiment after the different EDTA ap- plication methods (Figs. 1b and 1c). At 42nd d from EDTA application of $0.67 \mathrm{mmol} \times 6, \mathrm{Zn}$ and $\mathrm{Pb}$ concentrations in the soil solution had an increasing trend, and in addition, resulted in the maximum concentrations of $\mathrm{Cd}, \mathrm{Zn}$, and $\mathrm{Pb}$ in the soil solution. Application of $4 \mathrm{mmol} \times 1$ and 2 mmol $\times 2$ had lower concentrations of $\mathrm{Cd}$ and $\mathrm{Zn}$ in the soil solution compared with the other application methods.

The above results showed that applying EDTA at $4 \mathrm{mmol} \times 1$ or $2 \mathrm{mmol} \times 2$ can decrease the concentration of $\mathrm{Cd}, \mathrm{Zn}$, and $\mathrm{Pb}$ in the soil solution as well as the risk of groundwater contamination compared with the other treatments. Because of the frequent application of EDTA solutions in the $0.67 \mathrm{mmol} \times 6$, the EDTA-metal complex may not be degraded by the soil microorganisms during the 7-d period. Thus, the $\mathrm{Cd}, \mathrm{Zn}$, and $\mathrm{Pb}$ concentration in the soil solution had no tendency to decrease during the said period after applying 0.67 mmol EDTA $\mathrm{kg}^{-1}$.

\subsection{Effects on metal concentrations extracted by deionized water, 0.05 M EDTA, and 0.005 MDTPA}

The concentrations of metals extracted by deionized water from the soil were equal to that of the water-soluble fraction in the contaminated soil. In this study, the result of the deionized water-extractable metal concentration in the soil was similar to that of the soil solution. Among the four methods of EDTA application, 2 mmol $\times 2$ was more effective in decreasing the concentration of deionized water- extractable $\mathrm{Cd}, \mathrm{Zn}$, or $\mathrm{Pb}$ in the soil compared with the other methods (Fig. 2). Compared with the EDTA application of $0.67 \mathrm{mmol}$ $\times 6$, the method of $2 \mathrm{mmol} \times 2$ significantly decreased the deionized water-extractable $\mathrm{Cd}, \mathrm{Pb}$ and $\mathrm{Zn}$ by $39 \%, 50 \%$ and $31 \%(p<0.05)$, respectively.

There were no significant differences between the concentrations of $\mathrm{Cd}, \mathrm{Zn}$, or Pb extracted by 0.05 M EDTA (pH 7.0) (Fig. 3) and by $0.005 \mathrm{M}$ DTPA (pH 5.3) (data not shown) from the soil 


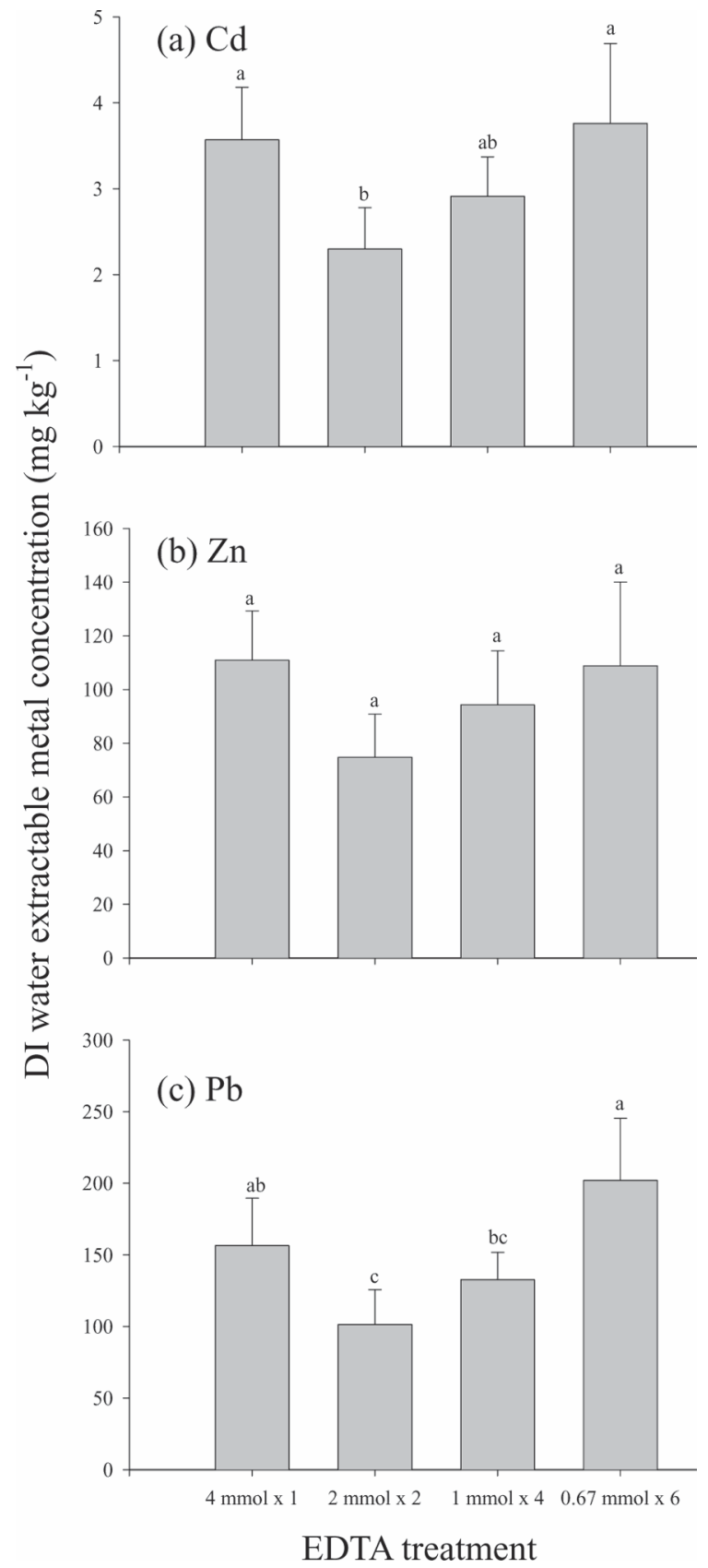

Fig. 2. The effect of different EDTA applying methods on the concentrations of (a) $\mathrm{Cd}$, (b) $\mathrm{Zn}$, and (c) Pb in soil extracted by deionized water. The probability level of significant difference is at $p=0.05$. Replicates $(n)=4$.

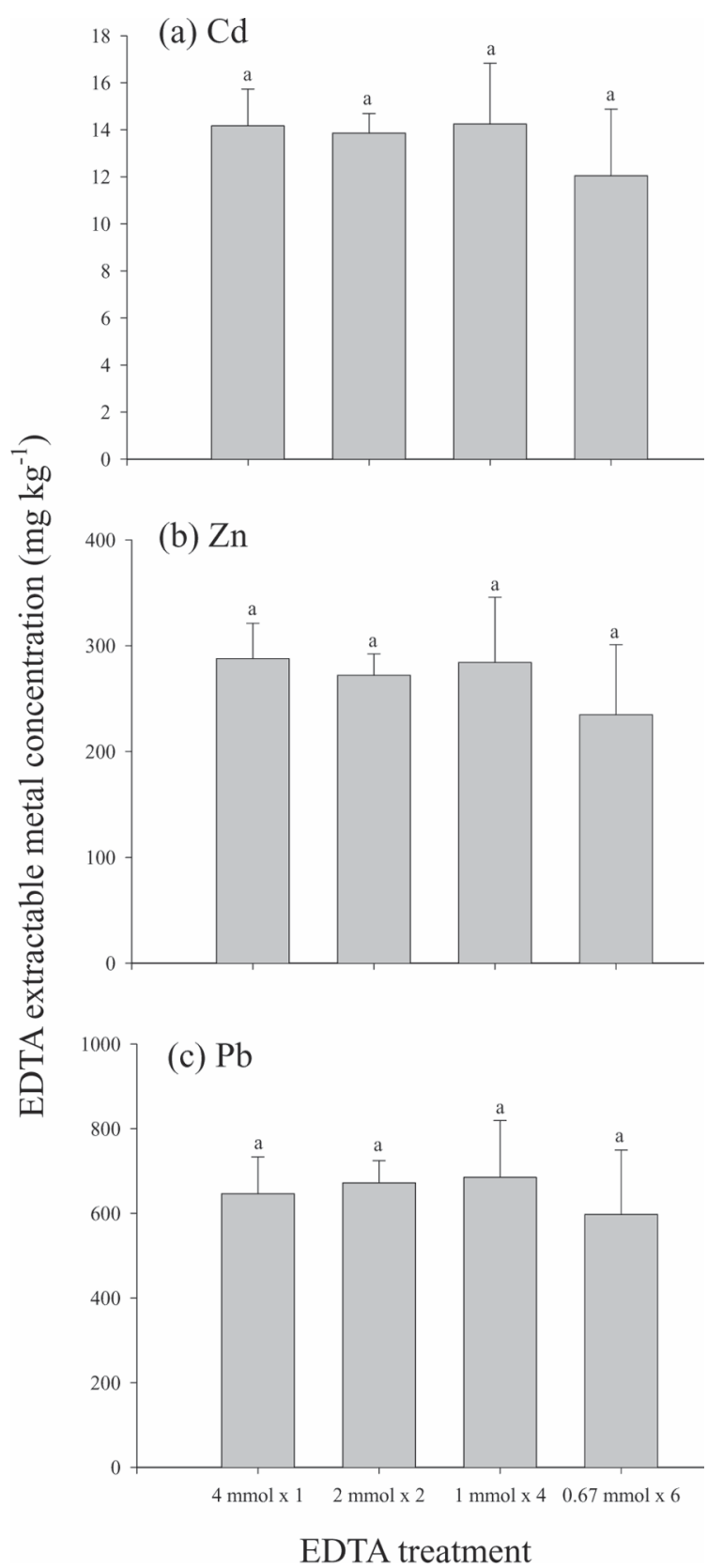

Fig. 3. The effect of different EDTA applying methods on the concentrations of (a) Cd, (b) Zn, and (c) Pb in soil extracted by $0.05 \mathrm{M}$ EDTA. The probability level of significant difference is at $p=0.05$. Replicates $(n)=4$. 
after EDTA application by different methods. Previous studies showed that $0.05 \mathrm{M}$ EDTA and 0.005 M DTPA were able to extract metals which were water-soluble, exchangeable, organic matter-bound, and even the fractions occluded in the oxides. The $0.05 \mathrm{M}$ EDTA (pH 7.0) extracted about $60-70 \%, 45-55 \%$, and $60-70 \%$ of the total $\mathrm{Cd}, \mathrm{Zn}$, and $\mathrm{Pb}$ concentration in the contaminated soil, respectively (Fig. 3). On the other hand, the 0.005 M DTPA (pH 5.3) extractable Cd, Zn, and $\mathrm{Pb}$ concentrations were about 100-120\%, 85$105 \%$, and $100-110 \%$ of their total concentrations, respectively (data not shown). The bioavailability of metals in artificially contaminated soil is higher than that of natural and long period of contaminated site [21]. Because of the short period of incubation in artificially contaminated soil, most of the metals in the different metal-treated soil we used existed in the fractions of high bioavailability including water soluble, exchangeable, or even bounded by organic matter. Because of the strong extracting capacity of both $0.05 \mathrm{M}$ EDTA and 0.005 M DTPA, which can extract most fractions of the metals in the soil studied, the $\mathrm{Cd}, \mathrm{Zn}$, and $\mathrm{Pb}$ concentrations in the extracts were not significantly different after applying EDTA by different methods. Similar to our previous study [26], experimental result of this study revealed that these two extracting methods are not suitable for assessing the artificially metals-contaminated soils.

The study revealed good relationships between the $\mathrm{Cd}, \mathrm{Zn}$, and $\mathrm{Pb}$ concentrations extracted by $0.05 \mathrm{M}$ EDTA and 0.005 M DTPA (Fig. 4). The values of correlation coefficients $\left(r^{2}\right)$ for $\mathrm{Cd}, \mathrm{Zn}$, and $\mathrm{Pb}$ were all bigger than $0.99(p<0.001)$. However, 0.005 M DTPA ( $\mathrm{pH}$ 5.3) extracted more amounts of metals in the combined metal-contaminated soil than $0.05 \mathrm{M}$ EDTA (pH 7.0). The concentrations of $\mathrm{Cd}, \mathrm{Zn}$, and $\mathrm{Pb}$ extracted by 0.005 M DTPA were 1.7, 1.8, and 1.6-fold more than that by $0.05 \mathrm{M}$ EDTA.

\subsection{Effects on the shoots of rainbow pink}

The different EDTA application methods af-

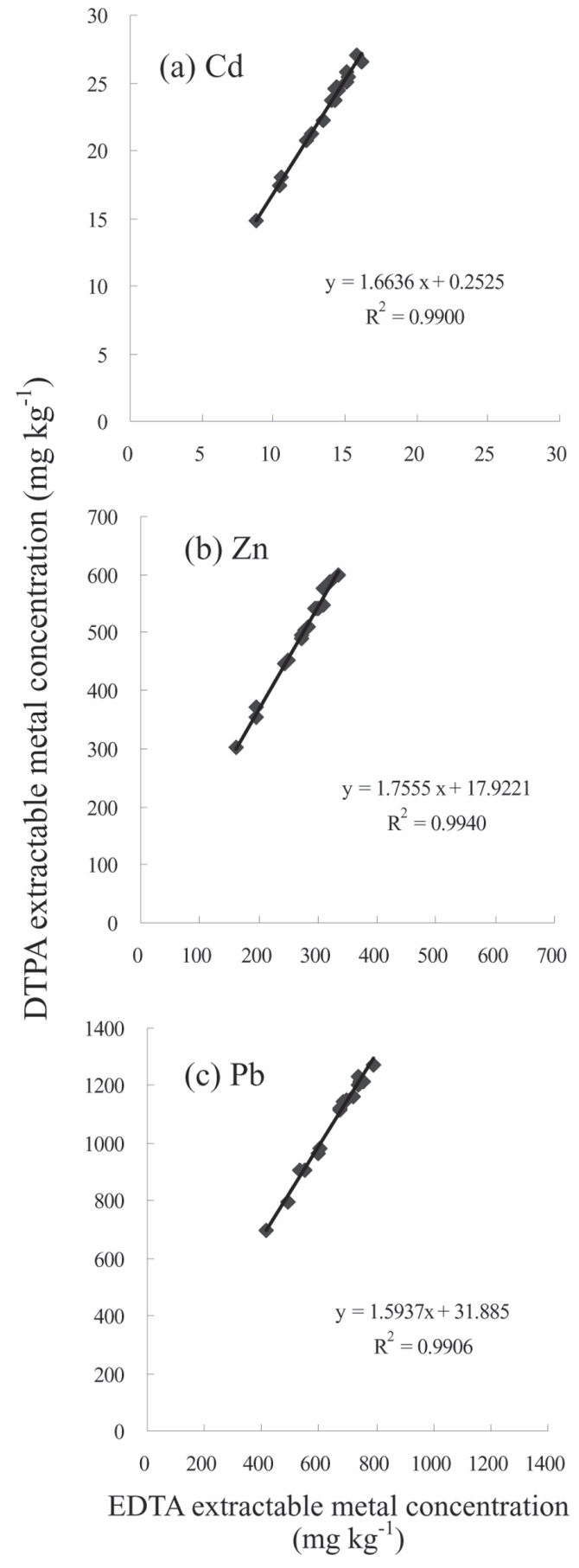

Fig. 4. The relationship between the concentrations of (a) $\mathrm{Cd}$, (b) $\mathrm{Zn}$, and (c) $\mathrm{Pb}$ in soil extracted by $0.05 \mathrm{M}$ EDTA and 0.005 M DTPA. 
fected the leaf appearance of rainbow pink after growing in the combined metals-contaminated soils for $49 \mathrm{~d}$ (picture not shown). The tips of some leaves showed symptoms of chlorosis after the EDTA application method of $4 \mathrm{mmol} \times 1$. Toxicities of metals might have occurred $7 \mathrm{~d}$ after applying 4 mmol EDTA kg-1 because of the higher concentrations of $\mathrm{Cd}, \mathrm{Zn}$, and $\mathrm{Pb}$ in the soil solution compared with the other application methods (Fig. 1). Although the $\mathrm{Cd}, \mathrm{Zn}$, and $\mathrm{Pb}$ concentrations in the soil solution or as extracted by deionized water from the soil changed with the EDTA application methods, the $\mathrm{Cd}, \mathrm{Zn}$, and $\mathrm{Pb}$ concentrations in the shoot of rainbow pink were not significantly affected by the different EDTA application methods. The $\mathrm{Cd}, \mathrm{Zn}$, and $\mathrm{Pb}$ concentrations in the shoot of rainbow pink were about 20-30, 450-650, and 250-350 $\mathrm{mg} \mathrm{kg}^{-1}$, respectively (Fig. 5). The result of Shen et al. [23] showed that multi-dose significantly increased the $\mathrm{Pb}$ concentrations in shoots of cabbage. However, there was no significant difference on the shoot $\mathrm{Cd}, \mathrm{Zn}$, or Pb concentration after applying EDTA using single or multi-dose methods. Possible reason response to the experimental result was the different characteristics of studied soils and physiological characters between cabbage and rainbow pink. The uptake of metals by rainbow pink reach the plateau and they cannot uptake metals anymore even the soil solution metal concentrations keep increasing after pot experiment in the treatment of $0.67 \mathrm{mmol} \times 6$. Although the shoot biomass was about $2.3-2.7$ g plant $^{-1}$ and was not significantly affected by the different EDTA application methods, this was only $60 \%$ of that observed in our previous study [25]. We suggest that some appropriate methods, like the application of fertilizer, should be used to increase the biomass of rainbow pink and thus to increase the total removal of metals from the contaminated soils. Total removal of $\mathrm{Cd}, \mathrm{Zn}$, and $\mathrm{Pb}$ were $0.07-0.08$, 1.3-1.6, and 0.70-0.80 mg plant ${ }^{-1}$, respectively (Fig. 6). Chen and Lee [24] proposed for the Cdcontaminated site of northern Taiwan, the plant-

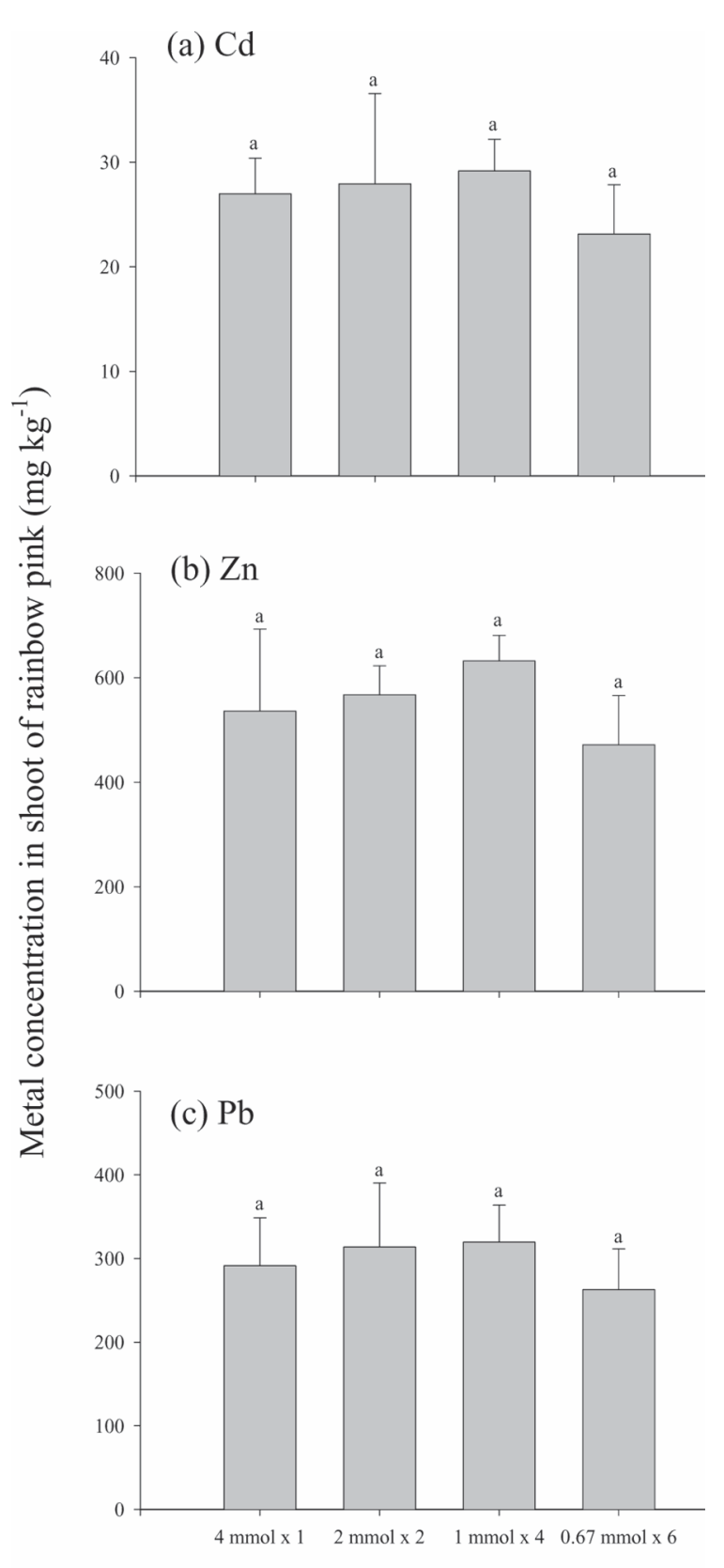

EDTA treatment

Fig. 5. The effects of different EDTA applying methods on the concentrations of (a) $\mathrm{Cd}$, (b) $\mathrm{Zn}$, and (c) $\mathrm{Pb}$ in the shoots of rainbow pink. The probability level of significant difference is at $p=0.05$. Replicates $(n)=4$. 


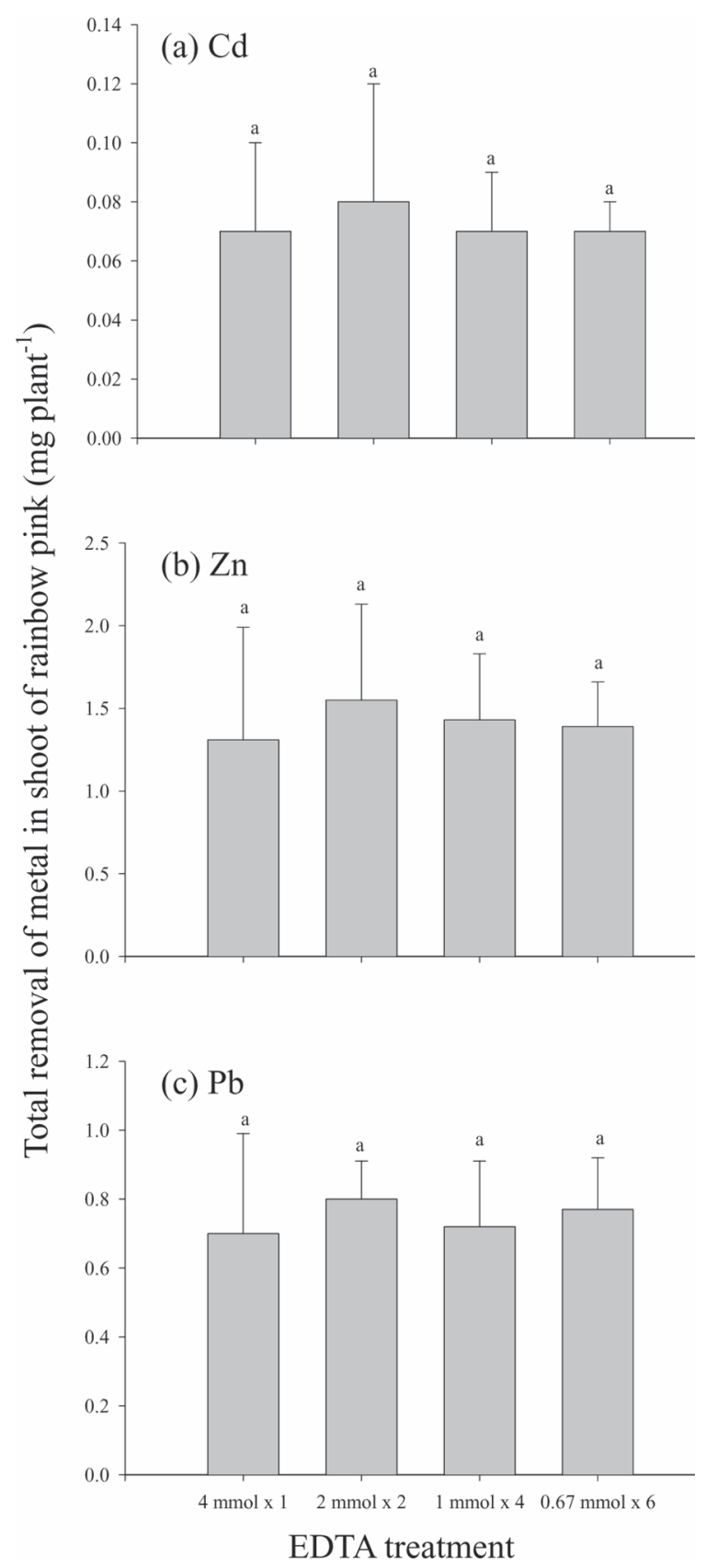

Fig. 6. The effects of different EDTA applying methods on the total removal of (a) Cd, (b) $\mathrm{Zn}$, and (c) $\mathrm{Pb}$ in the shoots of rainbow pink. The probability level of significant difference is at $p=0.05$. Replicates $(n)=4$. ing of rainbow pink four times per year using a planting density of 70,000 plants $\mathrm{ha}^{-1}$ to ensure the total removal of metals. The total removal of metals by the shoot of rainbow pink after applying 4 mmol EDTA $\mathrm{kg}^{-1}$ with different methods was about $30 \mathrm{~g} \mathrm{Cd}, 600 \mathrm{~g} \mathrm{Zn}$, and $300 \mathrm{~g} \mathrm{~Pb} \mathrm{ha}^{-1} \mathrm{y}^{-1}$, respectively.

The deionized water extractable $\mathrm{Cd}, \mathrm{Zn}$, and $\mathrm{Pb}$ concentration after applying 2Na-EDTA using different methods was in the ranges of 2.3$3.8 \mathrm{mg} \mathrm{Cd} \mathrm{kg}^{-1}, 75-110 \mathrm{mg} \mathrm{Zn} \mathrm{kg}{ }^{-1}$, and 100-200 $\mathrm{mg} \mathrm{Pb} \mathrm{kg}{ }^{-1}$, respectively (Fig. 2). The total removals of $\mathrm{Cd}, \mathrm{Zn}$, and $\mathrm{Pb}$ per plant per $\mathrm{kg}$ soil were in the ranges of $0.02-0.03,0.4-0.5$, and $0.2-$ $0.3 \mathrm{mg} \mathrm{kg}^{-1}$ soil, respectively. The calculated result showed that rainbow pink did not play an important role in decreasing the water soluble fractions of metals in our study. Our previous experimental result showed that rainbow pink accumulated about $80 \mathrm{mg} \mathrm{Cd} \mathrm{kg}^{-1}, 3,700 \mathrm{mg} \mathrm{Zn} \mathrm{kg}{ }^{-1}$, and $220 \mathrm{mg} \mathrm{Pb} \mathrm{kg}^{-1}$ in their shoots, respectively, when growing in the same artificially $\mathrm{Cd}-, \mathrm{Zn}-$, and $\mathrm{Pb}-$ contaminated soil for $50 \mathrm{~d}$ without applying $2 \mathrm{Na}$ EDTA. The experimental results of this study and our previous study $[25,26]$ revealed that although applying $2 \mathrm{Na}$-EDTA was significantly to increase the metal concentration in soil solution, but the potentiality of groundwater contamination also significantly increased. For phytoextraction of metals-contaminated soils in Taiwan using rainbow pink, direct planting them without applying $2 \mathrm{Na}-\mathrm{EDTA}$ is a better option compared with chemical-enhanced methods.

\section{Conclusion}

Application of 4 mmol EDTA kg-1 to the combined metals-contaminated soils at $4 \mathrm{mmol} \mathrm{\textrm {kg } ^ { - 1 }}$ at one time and $2 \mathrm{mmol} \mathrm{kg}^{-1}$ two times significantly decreased the $\mathrm{Cd}, \mathrm{Zn}$, and $\mathrm{Pb}$ concentrations in the soil solution compared with that when applied at $0.67 \mathrm{mmol} \mathrm{kg}^{-1}$ six times $(p<0.05)$. Application of $2 \mathrm{mmol} \mathrm{kg}^{-1}$ two times also significantly decreased the concentrations of $\mathrm{Cd}$ and 
$\mathrm{Pb}$ in the soil extracted by deionized water compared with the application of $0.67 \mathrm{mmol} \mathrm{\textrm {kg } ^ { - 1 }}$ six times $(p<0.05)$. However, no significant decrease was observed for the extraction methods using $0.05 \mathrm{M}$ EDTA or $0.005 \mathrm{M}$ DTPA because of their stronger extraction capacity than that of deionized water. However, good relationships were observed between the metal concentrations in the soil that were extracted by $0.05 \mathrm{M}$ EDTA and $0.005 \mathrm{M}$ DTPA. Although there were significant effects of the different EDTA application methods on the concentrations of metals in the soil solutions or in the soil extracted by deionized water $(p<0.05)$, there were no significant effects on the concentration and total removal of metals by the shoots of rainbow pink. The results also showed that when we apply a total amount of 4 mmol EDTA $\mathrm{kg}^{-1}$ to the Cd-, Zn-, and Pb-contaminated soil, or at $2 \mathrm{mmol} \mathrm{\textrm {kg } ^ { - 1 }}$ applied two times, it significantly decreased the risk of groundwater contamination compared with the other application methods.

\section{References}

[1] R.L. Chaney, M. Malik, Y.M. Li, S.L. Brown, E.P. Brewer, J.S. Angle and A.J.M. Baker, Phytoremediation of soil metals. Environ. Biotechnol., 8 (1997) 279-284.

[2] P.B.A.N Kumar, V. Dushenkov, H. Motto and I. Raskin, Phytoextraction: the use of plants to remove heavy metals from soils. Environ. Sci. Technol., 29 (1995) 1232-1238.

[3] M.M. Lasat, Phytoextraction: a review of biological mechanisms. J. Environ. Qual., 31 (2002) 109120.

[4] E. Lombi, W.W. Wenzel and D.C. Adriano, Soil contamination, risk reduction and remediation. Land Contamin. Reclam., 6 (1998) 183-197.

[5] W.W. Wenzel, E. Lombi and D.C. Adriano, Biogeochemical processes in the rhizosphere: Role in phytoremediation of metal-polluted soils. In: M.N.V. Prasad and J. Hagemeyer, eds., Heavy Metal Stress in Plants. Springer, New York, USA, 1999, pp. 273303.

[6] A. Sas-Nowosielska, R. Kucharski, E. Malkowski,
M. Pogrzeba, J.M. Kuperberg and K. Kyrnski, Phytoextraction crop disposal-an unsolved problem. Environ. Pollut., 128 (2004) 373-379.

[7] A.J.M. Baker, S.P. McGrath, R.D. Reeves and J.A.C. Smith, Metal hyperaccumulator plants: A review of the ecology and physiology of a biological resource for phytoremediation of metal-polluted soils. In: $\mathrm{N}$. Terry and G. Bañuelos, eds., Phytoremediation of Contaminated Soil and Water. CRC Press LLC, USA, 2000, pp. 85-107.

[8] M.J. Blaylock, D.E. Salt, S. Dushenkov, O. Zakharova, C. Gussman, Y. Kapulnik, B.D. Ensley and I. Raskin, Enhanced accumulation of $\mathrm{Pb}$ in Indian mustard by soil-applied chelating agents. Environ. Sci. Technol., 31 (1997) 860-865.

[9] J.W. Huang, J. Chen, W.R. Berti and S.D. Cunningham, Phytoremediation of lead-contaminated soils: Role of synthetic chelates in lead phytoextraction. Environ. Sci. Technol., 31 (1997) 800-805.

[10] X.J. Jiang, Y.M. Luo, Q.G. Zhao, A.J.M. Baker, P. Christie and M.H. Wong, Soil Cd availability to Indian mustard and environmental risk following EDTA addition to Cd-contaminated soil. Chemosphere, 50 (2003) 813-818.

[11] E. Lombi, F.J. Zhao, S.J. Dunham and S.P. McGrath, Phytoremediation of heavy metal-contaminated soils: natural hyperaccumulation versus chemically enhanced phytoextraction. J. Environ. Qual., 30 (2001) 1919-1926.

[12] J. Wu, F.C. Hsu and S.D. Cunningham, Chelate-assisted $\mathrm{Pb}$ phytoremediation: $\mathrm{Pb}$ availability, uptake, and translocation constraints. Environ. Sci. Technol., 33 (1999) 1898-1904.

[13] L.H. Wu, Y.M. Luo, X.R. Xing and P. Christie, EDTA-enhanced phytoremediation of heavy metal contaminated soil with Indian mustard and associated potential leaching risk. Agric. Ecosys. Environ., 102 (2004) 307-318.

[14] A. Kayser, K. Wenger, A. Keller, W. Attinger, H.R. Felix, S.K. Gupta and R. Schulin, Enhancement of phytoextraction of $\mathrm{Zn}, \mathrm{Cd}$, and $\mathrm{Cu}$ from calcareous soil: The use of NTA and sulfur amendments. Environ. Sci. Technol., 34 (2000) 1778-1783.

[15] T. Macek, M. Macková, D. Pavlíková, J. Száková, M. Truksa, A.S. Cundy, P. Kotrba, N. Yancey and W.H. Scouten, Accumulation of cadmium by transgenic tobacco. Acta. Biotechnol., 22 (2002) 101-106.

[16] E.A.H. Pilon-Smits, S. Hwang, C.M. Lytle, Y. Zhu, 
J.C. Tai, R.C. Bravo, Y. Chen, T. Leustek and N. Terry, Overexpression of ATP sulfurylase in Indian mustard leads to increased selenate uptake, reduction, and tolerance. Plant Physiol., 119 (1999) 123132.

[17] C. Rensing, U. Kües, U. Stahl, D.H. Nies and B. Friedrich, Expression of bacterial mercuric ion reductase in Saccharomyces cerevisiae. J. Bateriol., 174 (1992) 1288-1292.

[18] S.D. Cunningham and D.W. Ow, Promises and prospects of phytoremediation. Plant Physiol., 110 (1996) 715-79.

[19] B.D. Ensley, I. Raskin and D.E. Salt, Phytoremediation application for removing heavy metal contamination from soil and water. In: G.S. Sayler, J. Sanseverion and K.L. Davis, eds., Biotechnology in the Sustainable Environment. Plenum Press, New York, USA, 1997, pp. 59-64.

[20] S.D. Ebbs and L.V. Kochian, Phytoextraction of zinc by oat (Avena sativa), barley (Hordeum vulgare), and Indian mustard (Brassica juncea). Environ. Sci. Technol., 32 (1998) 802-806.

[21] P. Römkens, L. Bouwman, J. Japenga and C. Draaisma, Potentials and drawbacks of chelate-enhanced phytoremediation of soils. Environ. Pollut., 116 (2002) 109-121.

[22] S.A. Wasay, S.F. Barrington and S. Tokunaga, Remediation of soils polluted by heavy metals using salts of organic acids and chelating agents. Environ. Technol., 19 (1998) 369-380.

[23] Z.G. Shen, X.D. Li, C.C. Wang, H.M. Chen and H. Chua, Lead phytoextraction from contaminated soil with high-biomass plant species. J. Environ. Qual., 31 (2002) 1893-1900.

[24] Z.S. Chen and D.Y. Lee, Evaluation of remediation techniques on two cadmium-polluted soils in Taiwan. In: I.K. Iskandar and D.C. Adriano, eds., Remediation of Soils Contaminated with Metals. Science Reviews, Northwood, UK, 1997, pp. 209-223.

[25] H.Y. Lai and Z.S. Chen, Effects of EDTA on solubility of cadmium, zinc, and lead and their uptake by rainbow pink and vetiver grass. Chemosphere, 55 (2004) 421-430.

[26] H.Y. Lai and Z.S. Chen, The effect of EDTA on phytoextraction of single and combined metals-contaminated soils by rainbow pink. Chemosphere, 60
(2005) 1062-1071.

[27] E.O. McLean, Soil pH and lime requirement. In: A.L. Page et al., eds., Methods of Soil Analysis. Part 2. Chemical and Microbiological Properties, 2nd ed., Madison, WI, USA, Agronomy Monograph 9, 1982, pp. 199-224.

[28] G.W. Gee and J.W. Bauder, Particle-size analysis. In: A. Klute, C.S. Campbell, D.R. Nielsen, R.D. Jackson and M.M. Mortland, eds., Methods of Soil Analysis. Part 1. Physical and Mineralogical Method, 2nd ed., Madison, WI, USA, Agronomy Monograph 9, 1986, pp. 383-412.

[29] D.W. Nelson and L.E. Sommers, Total carbon, organic carbon, and organic matter. In: A.L. Page et al., eds., Methods of Soil Analysis. Part 2. Chemical and Microbiological Properties, 2nd ed., Madison, WI, USA, Agronomy Monograph 9, 1982, pp. 539-580.

[30] J.K. Rhoades, Cation exchange capacity. In: A.L. Page et al., eds., Methods of Soil Analysis. Part 2. Chemical and Microbiological Properties, 2nd ed., Madison, WI, USA, Agronomy Monograph 9, 1982, pp. 149-158.

[31] G.W. Thomas, Exchangeable cations. In: A.L. Page et al., eds., Methods of Soil Analysis. Part 2. Chemical and Microbiological Properties, 2nd ed., Madison, WI, USA, Agronomy Monograph 9, 1982, pp. 159-166.

[32] EPA/ROC, The Digestion Methods of Heavy Metal in Soils by Aqua Regia. Method code No: NIEA S321.62C. Environmental Protection Administration of Taiwan ROC, Taipei, Taiwan, 2002.

[33] M.E. Harmon and K. Lajtha, Analysis of detritus and organic horizons for mineral and organic constitutes. In: G.P. Robertson, D.C. Coleman, C.S. Bledsoe and P. Sollins, eds., Standard Soil Methods for Long-Term Ecological Research. Oxford University Press, Inc., New York, USA, 1999, pp. 143165.

[34] M.J. Mench, V.L. Didier, M. Loffler, A. Gomez and P. Masson, A mimicked in-situ remediation study of metal-contaminated soils with emphasis on cadmium and lead. J. Environ. Qual., 23 (1994) 58-63.

[35] W.L. Lindsay and W.A. Norvell, Development of a DTPA soil test for zinc, iron, manganese, and copper. Soil. Sci. Soc. Am. J., 42 (1978) 421-428. 